Paedagogia Christiana

I/27 (20I I) - ISSN 1505-6872

Jan Śledzianowski*

Kielce

\title{
Autorytet rodzicielski w Rodzinie Nazaretańskiej i dzisiaj
}

Pedagogika chrześcijańska, podobnie jak każda roślina życiodajna soki pobiera przez korzenie z gleby, tak dla niej ową glebą są Pismo Święte i Tradycja - źródło mądrości i wiedzy pedagogicznej w dziedzinie wychowania i kształtowania młodego pokolenia. Wyjątkową wartość dla wyznawców Chrystusa mają Ewangelie, które ukazują dzieciństwo, wzrastanie i dojrzewanie Jezusa, Syna Bożego, w środowisku rodzinnym i ludzkim, jakim była Rodzina Józefa i Maryi mieszkająca w Nazarecie.

\section{Powstanie Rodziny Nazaretańskiej}

Podstawowymi źródłami wiedzy o powstaniu Rodziny Nazaretańskiej są Ewangelie: św. Łukasza i św. Mateusza. Tradycja i sam autor trzeciej Ewangelii i Dziejów Apostolskich wskazują, że lekarz Łukasz, towarzysz podróży apostolskich św. Pawła, bezpośrednio spotykał się z Matką Jezusa Chrystusa. W pierwszym więc źródle znajdujemy informację:

W szóstym miesiącu posłał Bóg anioła Gabriela do miasta w Galilei, zwanego Nazaret, do Dziewicy poślubionej mężowi, imieniem Józef, z rodu Dawida; a Dziewicy było na imię Maryja. Anioł wszedł do Niej i rzekł: «Bądź pozdrowiona, pełna łaski, Pan z Tobą, błogosławiona jesteś między niewiastami». Ona

* Ks. prof. dr hab. Jan Śledzianowski, obecnie zatrudniony w Krakowskiej Akademii im. Andrzeja Frycza Modrzewskiego na Wydziale Psychologii i Nauk o Rodzinie. 
zmieszała się na te słowa i rozważała, co miałoby znaczyć to pozdrowienie. Lecz anioł rzekł do Niej: «Nie bój się Maryjo, znalazłaś bowiem łaskę u Boga. Oto poczniesz i porodzisz Syna, któremu nadasz imię Jezus. Będzie On wielki i będzie nazywany Synem Najwyższego, a Pan Bóg da Mu tron Jego praojca Dawida. Będzie panował nad domem Jakuba na wieki, a Jego panowaniu nie będzie końca». Na to Maryja rzekła do anioła: «Jakże się to stanie, skoro nie znam męża?». Anioł jej odpowiedział: «Duch Święty zstąpi na Ciebie i moc Najwyższego osłoni Cię. Dlatego też Święte, które się narodzi, będzie nazwane Synem Bożym. A oto również krewna Twoja Elżbieta, poczęła w swej starości syna i już w szóstym miesiącu ta, która uchodzi za niepłodną». Na to rzekła Maryja: «Oto Ja służebnica Pańska, niech Mi się stanie według twego słowa». Wtedy odszedł od Niej anioł (Łk 1, 26-38).

Z powyższego przekazu Ewangelii dowiadujemy się, że Maryja już jest poślubioną przez św. Józefa małżonka, jest jednak Dziewica, bowiem - jak sama stwierdza - „nie zna męża”, czyli nie współżyła z mężem i ma istotną wątpliwość: jak może począć i urodzić Syna: „skoro nie znam męża”. Gdy dowiedziała się, iż poczęcie nastąpi za sprawą Ducha Świętego, posłuszna Bogu wyraziła zgodę, aby być matką Syna Bożego. Tego ważnego wydarzenia, iż poczęła i stała się Matką Zbawiciela, nie przekazała małżonkowi. Być może uznała, iż zbyt wielką tajemnicę nosi w łonie, aby mógł ją zrozumieć św. Józef. Natomiast Maryja zaraz zdecydowała się odwiedzić krewną Elżbietę, która od pół roku już była matką.

Przy wzajemnym powitaniu Elżbieta powiedziała: „Błogosławiona jesteś między niewiastami i błogosławiony jest owoc Twojego łona. A skądże mi to, że Matka mojego Pana przychodzi do mnie? Oto, skoro głos Twojego pozdrowienia zabrzmiał w moich uszach, poruszyło się z radości dzieciątko w moim łonie. Błogosławiona jesteś, któraś uwierzyła, że spełnią się słowa powiedziane Ci od Pana" (Łk 1, 42-45).

Elżbieta wraz z małżonkiem Zachariaszem przywitali Maryję jako nie tylko krewną, ale przede wszystkim jako Matkę ich Pana, czyli Matkę Syna Bożego. Maryja przebywa w domu Zachariasza i Elżbiety „około trzech miesięcy; potem wróciła do domu" (Łk 1, 56), czyli była obecna przy narodzeniu syna Zachariasza i Elżbiety, św. Jana Chrzciciela.

Po powrocie Maryi z południowej Judei do północnej Galilei i do Nazaretu Józef zauważył:

wpierw, nim zamieszkali razem, znalazła się brzemienną za sprawą Ducha Świętego. Mąż Jej Józef - pisze św. Mateusz - był człowiekiem sprawiedliwym i nie chciał narazić Jej na zniesławienie, zamierzał oddalić Ją potajemnie. Gdy powziął tę myśl, oto anioł Pański ukazał mu się we śnie i rzekł: „Józefie, synu 
Dawida, nie bój się wziąć do siebie Maryi, twej Małżonki; albowiem z Ducha Świętego jest to, co się w Niej poczęło. Porodzi Syna, któremu nadasz imię Jezus. On bowiem zbawi swój lud od jego grzechu" [...] Zbudziwszy się ze snu, Józef uczynił tak, jak mu polecił anioł Pański: wziął swoją Małżonkę do siebie (Mt 1, 18b-21.24).

Tak ukształtowała się Rodzina Nazaretańska - można powiedzieć, że nie według prawa naturalnego, lecz wedle prawa objawionego Maryi i Józefowi przez Boga. Papież Jan Paweł II napisał: „Przyznając Józefowi ojcowską władzę nad Jezusem, Bóg napełnił go także miłością ojcowską, tą miłością, która ma swoje źródło w Ojcu , «od którego bierze nazwę wszelkie ojcostwo na niebie i na ziemi» (por. Ef 3,15$)$ " (RC 8) ${ }^{1}$.

Dalej Ojciec Święty Jan Paweł II pisał:

Udając się do Betlejem z powodu spisu ludności, stosownie do zarządzenia prawowitej władzy, Józef spełnił wobec dziecka ważne i znamienne zadanie, by oficjalnie wpisać do rejestrów Cesarstwa imię «Jezus, syn Józefa z Nazaretu» (por. J 1, 45). Zapis ten ukazał w sposób jawny, że Jezus należy do rodzaju ludzkiego, że jest człowiekiem pośród ludzi, obywatelem tego świata, podległym prawom i instytucjom państwowym, ale także „Zbawicielem świata” (RC 9).

O tym, że Jezus jest synem Józefa cieśli, będą wiedzieć wszyscy w Nazarecie, natomiast, iż jest On Synem Bożym i Zbawicielem świata, wie tylko Maryja i Józef, jako powiernicy tajemnicy ,przed wiekami ukrytej w Bogu”.

\section{Proces wychowania w Rodzinie Nazaretańskiej}

Proces wychowywania Dzieciątka przez rodziców rozpoczął się już w okresie prenatalnym, szczególnie w tych długich i uciążliwych dniach dla Maryi, gdy z Nazaretu musieli odbyć podróż do Betlejem, aby dopełnić obowiązku narzuconego przez cezara Augusta - spisu ludności. W drodze i w Betlejem św. Józef dawał poczucie bezpieczeństwa Maryi i Dzieciątku w bardzo trudnej sytuacji bytowej, co zapisał ewangelista Łukasz: „Kiedy tam przebywali, nadszedł dla Maryi czas rozwiązania. Porodziła swego pier-

${ }^{1}$ Jan Paweł II, Adhortacja apostolska Redemptoris Custos o św. Józefie i jego posłannictwie w życiu Chrystusa i Kościoła, w: Adhortacje Ojca Świętego Jana Pawła II, Kraków 1997 (w tekście RC z odnośnym numerem). 
worodnego Syna, owinęła go w pieluszki i położyła w żłobie, gdyż nie było dla nich miejsca w gospodzie" (Łk 2, 6-7). Jan Paweł II stwierdza, iż

Józef był świadkiem naocznym tych narodzin, które dokonały się w warunkach po ludzku upokarzających, były więc pierwszą zapowiedzią owego dobrowolnego „wyniszczenia” (por. Flp 2, 5-8), jakie Chrystus przyjmuje na siebie dla odkupienia grzechów. Równocześnie też Józef był świadkiem pokłonu pasterzy, którzy przybyli na miejsce urodzin Jezusa, gdy anioł zaniósł im tę wielką radosną wiadomość (por. Łk 2, 15-16); był też później świadkiem pokłonu Mędrców ze Wschodu (por. Mt 2, 11) (RC 10).

Święty Józef podejmując rolę ojcowską wobec Jezusa, zgodnie z tradycją narodu izraelskiego, a zarazem zgodnie z objawieniem mesjańskim, poddaje Syna obrzezaniu, nadaje imię Jezus, ofiaruje czterdziestego dnia po narodzeniu w świątyni jerozolimskiej (por. RC 11-13).

Niezwykle trudne zadanie spada na Maryję i Józefa w związku z zagrożeniem życia Jezusa ze strony króla Heroda

oto anioł Pański ukazał się Józefowi we śnie i rzekł: „Wstań, weź Dziecię i Jego Matkę i uchodź do Egiptu, pozostań tam, aż ci powiem; bo Herod będzie szukał Dziecięcia, aby Je zgładzić”. [...] Józef, usłyszawszy we śnie ostrzeżenie, wziął w nocy Dziecię i Jego Matkę i udał się do Egiptu; tam pozostał aż do śmierci Heroda. Tak miało się spełnić słowo, które Pan powiedział przez Proroka: „z Egiptu wezwałem Syna mego” (Mt 2, 13-15; por. Oz 11, 1).

Ojciec Święty Jan Paweł II obecności Rodziny Nazaretańskiej w Egipcie nadaje głęboki sens historyczny i zbawczy w słowach: „Jak Izrael wszedł na szlak wyjścia «z domu niewoli», które to wyjście zapoczątkowało Stare Przymierze, tak i Józef, powiernik i współpracownik opatrznościowej tajemnicy Bożej, strzeże również na wygnaniu Tego, który wypełnia Nowe Przymierze" (RC 14).

Po kilkuletnim pobycie Świętej Rodziny w Egipcie św. Józef znów usłyszał słowa przekazane mu od Boga:

„Wstań weź Dziecię i Jego Matkę i idź do ziemi Izraela, bo już umarli ci, którzy czyhali na życie Dziecięcia". On więc wstał, wziął Dziecię i jego Matkę i wrócił do ziemi Izraela, lecz gdy posłyszał, że w Judei panuje Archelaos w miejsce ojca swojego, Heroda, bał się tam iść. Otrzymawszy zaś we śnie nakaz, udał się do Galilei. Przybył do miasta, zwanego Nazaret, i tam się osiedlił. Tak miało się spełnić słowo Proroków: „Nazwany będzie Nazarejczykiem” (Mt 2, 20-23). 
Ojciec Święty Jan Paweł II, zagłębiając się w życie Świętej Rodziny, pisze:

Od chwili zwiastowania znalazł się Józef - wraz z Maryją - niejako wewnątrz tajemnicy „od wieków ukrytej w Bogu”, która przyoblekła się w ciało: „Słowo stało się ciałem i zamieszkało wśród nas” (J 1, 14). Zamieszkało wśród ludzi, w świętej Rodzinie Nazaretańskiej - jednej z wielu rodzin tego galilejskiego miasteczka, jednej z wielu rodzin na ziemi Izraela. Tam Jezus wzrastał, „nabierał mocy, napełniał się mądrością, a łaska Boża spoczywała na Nim” (por. Łk 2, 40). Ewangelia streszcza w kilku słowach ten długi okres życia „ukrytego", poprzez który Jezus z Nazaretu przygotowuje się do swojego mesjańskiego posłannictwa. [...] Wzrastanie Jezusa „w mądrości, w latach i w łasce” (Łk 2, 52) dokonywało się w środowisku świętej Rodziny, pod opieką Józefa, na którym spoczywało wzniosłe zadanie „wychowania”, czyli żywienia i odziewania Jezusa, nauczania Go Prawa i zawodu zgodnie z powinnościami przypadającymi ojcu (RC 15-16).

W świetle dotychczasowych rozważań możemy stwierdzić, iż w Rodzinie Nazaretańskiej w procesie wychowania Jezusa spełniał św. Józef pierwszoplanową rolę, zgodnie z całą tradycją izraelska, poczynając od Abrahama. Szanuje tę tradycję i Matka Boża, co szczególnie jest widoczne, gdy dwunastoletni Jezus został w świątyni jerozolimskiej. Wydarzenie to opisuje św. Łukasz:

Rodzice Jego chodzili co roku do Jerozolimy na Święto Paschy. Gdy miał lat dwanaście, udali się tam zwyczajem świątecznym. Kiedy wracali po skończonych uroczystościach, został Jezus w Jerozolimie, a tego nie zauważyli Jego Rodzice. Przypuszczając, że jest w towarzystwie pątników, uszli dzień drogi i szukali Go wśród krewnych i znajomych. Gdy Go nie znaleźli, wrócili do Jerozolimy szukając Go. Dopiero po trzech dniach odnaleźli Go w świątyni, gdzie siedział między nauczycielami, przysłuchiwał się im i zadawał pytania. Wszyscy zaś, którzy Go słuchali, byli zdumieni bystrością Jego umysłu i odpowiedziami. Na ten widok zdziwili się bardzo, a Jego Matka rzekła do Niego „Synu czemuś nam to uczynił? Oto ojciec Twój i ja z bólem serca szukaliśmy Ciebie”. Lecz On im odpowiedział: „Czemuście Mnie szukali? Czy nie wiedzieliście, że powinienem być w tym, co należy do mego Ojca?” Oni jednak nie rozumieli tego, co im powiedział (Łk 2, 41-50).

Zauważmy, że Maryja, zwracając się do Jezusa w świątyni jerozolimskiej po trzech dniach poszukiwania, mówi: „Synu, czemuś nam to uczynił? Oto ojciec Twój i ja z bólem serca szukaliśmy Ciebie”. Nie mówi jedynie o sobie, o swoim bólu... Wobec nauczycieli, z którymi dyskutował Jezus, sta- 
wia małżonka Józefa na pierwszym planie, zgodnie z tradycją Izraela: „Oto ojciec Twój i ja z bólem serca szukaliśmy ciebie”. W słowach tych wyraża wspólny ból, wspólne niepokoje i lęki, które przeżywali poszukując Syna. Jednocześnie podkreśla autorytet Józefa, jego troskę o wychowanie, wyraża też wdzięczność za to, że Józef jest z nią zawsze obecny, szczególnie w momentach zagrożenia dla Jezusa. Oczywiście, iż Maryja używając określenia „ojciec” w stosunku do Józefa doskonale wie, że Józef nie jest rzeczywistym ojcem, lecz spełnia ludzką, ojcowską władzę i opiekę nad Synem. Wie o tym, kim jest dwunastoletni Jezus, gdy odpowiada: „Czemuście Mnie szukali? Czy nie wiedzieliście, że powinienem być w tym, co należy do mego Ojca?”.

W tym momencie wróćmy raz jeszcze do adhortacji apostolskiej Redemptoris custos Jana Pawła II:

Słyszał tę odpowiedź Józef, o którym przez chwilę Maryja powiedziała „ojciec Twój”. Wszyscy tak mówili i tak myśleli. Jezus był ,jak mniemano, synem Józefa" (Łk 3,23). Niemniej, odpowiedź Jezusa w świątyni musiała odnowić w świadomości „domniemanego ojca” to, co usłyszał owej nocy, przed dwunastu laty: „Józefie... nie bój się wziąć do siebie Maryi, twej Małżonki; albowiem z Ducha Świętego jest to, co się w Niej poczęło". Od tego momentu Józef wiedział, że jest powiernikiem Bożej tajemnicy. Jezus dwunastoletni nazwał tę tajemnicę po imieniu ,powinienem być w tym, co należy do mego Ojca” (RC 15).

\section{Odkrywanie podmiotowości i tożsamości przez Jezusa}

Pobożni małżonkowie Maria i Józef, jak podkreśla ewangelista Łukasz, co roku chodzili do Jerozolimy na Święto Paschy. Dodajmy, iż dla Izraelitów było to najważniejsze święto w roku. Szczególnie zapisało się to święto w sercu Maryi (Łk 2, 51b), gdy Jezus miał lat dwanaście. Dotąd bowiem żył i wzrastał jak każde dziecko, można powiedzieć, że „przedmiotowo” był rodzicom w Nazarecie poddany. Tutaj w Jerozolimie ,zgubił się” i tak postrzegają go Józef i Maryja w czasie poszukiwań. Tymczasem Jezus szukał swej tożsamości: kim JEST. Szukał jej w świątyni, która dla Izraela była miejscem przymierza i spotkania narodu z Bogiem. Dla swojej tożsamości szukał potwierdzenia u ludzi mądrych, znaczących dla narodu wybranego, bowiem gdy Go rodzice odnaleźli ,siedział między nauczycielami, przysłuchiwał się im i zadawał pytania. Wszyscy zaś, którzy Go słuchali, byli zdumieni bystrością Jego umysłu i odpowiedziami” (Łk 2, 46-47).

Po ludzku patrząc na to wydarzenie, widzimy je tak, jak je doświadczali Maryja i Józef - zagubienie Jezusa przez trzy doby. Dziś byśmy powiedzieli, iż było to samowolne opuszczenie rodziców. A dla Jezusa jest to 
potwierdzenie swojej tożsamości. Dwunastolatek doskonale wie, kim JEST i gdzie powinien być: „Czy nie wiedzieliście, że powinienem być w tym, co należy do mego Ojca?”. Więc nie jest to zagubienie, lecz odkrycie przed Maryją i Józefem swojej tożsamości, swojej podmiotowości i swojego pochodzenia od Boga Ojca. Ksiądz Zdzisław Pawłowski twierdzi, iż w opisie tego wydarzenia św. Łukasz ukazał paradygmat dojrzewania Jezusa jako nauczyciela ${ }^{2}$.

Mimo owej świadomości dwunastoletni Jezus nie został w świątyni, nie wybrał uczonych, lecz poszedł z nimi i „wrócił do Nazaretu; i był im poddany $[. .$.$] czynił postępy w mądrości, w latach i w łasce u Boga i u ludzi”$ (Łk 2, 51-52).

W życiu indywidualnym jako chrześcijanie jesteśmy zobowiązani naśladować Pana Jezusa: „Jeśli kto chce pójść za Mną, niech się zaprze samego siebie, niech weźmie krzyż swój i niech Mnie naśladuje" (Mk 8, 34). Krzyżem własnym dla każdego człowieka są różne słabości, braki wrodzone czy nabyte przez zaniedbanie. Często krzyż, który dźwigamy, jest skutkiem naszego nieodpowiedzialnego wyboru i działania. Może jego ciężar okazać się dotkliwy nie tylko dla nas, lecz także dla osób, z którymi razem żyjemy, pracujemy. Owe obciążenie ciężarem krzyża szczególnie jest dotkliwe w relacjach małżeńskich: mąż-żona i w relacjach rodzinnych: rodzice-dzieci. Tutaj wzorem do naśladowania dla nas jest Rodzina Nazaretańska.

\section{Autorytet rodzicielski przeniesiony z Nazaretu do współczesnych rodzin}

Odnosząc wychowanie w dzisiejszej chrześcijańskiej rodzinie do Świętej Rodziny Jezusa, Maryi i Józefa z Nazaretu, przenosimy je na płaszczyznę naturalnego ziemskiego życia, ale także nadprzyrodzonego, religijnego.

Wychowanie religijne łączy się najściślej z życiem człowieka na ziemi, $z$ jego celem, sensem i przeznaczeniem. Przez praktykowanie cnoty religijności, czyli oddawanie Bogu należnej czci i miłości, człowiek upodabnia się do Stwórcy, na którego obraz i podobieństwo powołany jest do życia (por. Rdz 1, 27). Życie religijne, które przez wychowanie staje się udziałem dziecka, otwiera je na rzeczywistość: duchową, transcendentna, nieśmiertelną i wieczną. Można powiedzieć, że wychowanie religijne jest dalszym tworzeniem dziecka na obraz i podobieństwo Boga i z samej natury prokreacji, w którym uczestniczą rodzice, im przysługuje.

${ }^{2}$ Z. Pawłowski, Biblijne podstawy formacji młodzieży, referat wygłoszony we Wrocławiu 27 kwietnia 2009 r. na Ogólnopolskim Sympozjum: Pokolenie JP2 i B16. 
Kościół zawsze nauczał, że rodzicom przysługuje podstawowe prawo wychowania religijnego dziecka. Dla rodziców chrześcijańskich prawo to wynika z sakramentu chrztu dziecka. W ostatnich czasach Kościół często przypomina rodzicom o tym ich obowiązku: „Każdej rodzinie, jako społeczności cieszącej się własnym pierwotnym prawem, przysługuje uprawnienie do swobodnego organizowania życia religijnego w ognisku domowym pod kierunkiem rodziców" (DWCH 5)3. Ojciec Święty Jan Paweł II wzywa rodziców, aby przekazywali dzieciom życie moralne i duchowe, aby wychowywali je na chwałę Bożą przez ustawiczne wychowywanie w wierze (por. FC 28, 38, 51) ${ }^{4}$. W Karcie Praw Rodziny Stolica Apostolska upomina się o prawo wychowania dzieci przez rodziców: „Rodzice mają prawo do wychowania dzieci zgodnie ze swoimi przekonaniami moralnymi i religijnymi, z uwzględnieniem tradycji kulturowych rodziny” (KPR 5) . „Każdej rodzinie przysługuje uprawnienie do swobodnego organizowania życia religijnego w ognisku domowym pod kierunkiem rodziców, jak również prawo do publicznego wyznawania i głoszenia swojej wiary, uczestniczenia w kulcie publicznym oraz swobodnego wyboru programów wychowania religijnego, bez podlegania z tego powodu jakiejkolwiek dyskryminacji” (KPR 7).

Można powiedzieć, iż Rodzina Nazaretańska, choć żyła w niewoli rzymskiej i podlegała różnym ograniczeniom, wypełniała praktyki religijne - te prywatne w zaciszu rodzinnego domu i te publiczne w synagodze w Nazarecie, czy te religijno-narodowe w świątyni jerozolimskiej. Na szczególne podkreślenie w praktykach religijnych Maryi i Józefa zasługują fakty, iż „Rodzice Jezusa chodzili co roku do Jerozolimy na Święto Paschy” (Łk 2,41). A więc oboje dawali przykład religijnego życia. Jest to niezwykle ważne dla dziecka, gdy rodzice razem się modlą, harmonijnie wspierają się przed Bogiem i ów obraz jedności przekazują dzieciom. Rozdwojenie postaw rodzicielskich w zakresie religijnego wychowania jest szkodliwe dla dzieci, może pozbawić je autentycznego przeżywania relacji z Panem Bogiem; może wnieść w życie dziecka dwutorowość za przykładem różnych zachowań i przeżyć religijności przez matkę i ojca.

Pójdźmy dalej - wychowanie ogarnia całe życie dziecka. Ono także ma swój krzyż: niepowodzenia w szkole, kłopoty z rówieśnikami, kłopoty z samym sobą, szczególnie gdy przekracza dwunasty rok życia. Właśnie okres

${ }^{3}$ Deklaracja o wychowaniu chrześcijańskim Gravissimum educationis, w: Sobór Watykański II. Konstytucje. Dekrety. Deklaracje, Poznań 1968 - w tekście DWCH z odnośnym numerem.

4 Jan Paweł II, Adhortacja apostolska Familiaris consortio o zadaniach rodziny chrześcijańskiej w świecie wspótczesnym, w: Adhortacje, - w tekście FC z odnośnym numerem.

${ }^{5}$ Karta Praw Rodziny, „L'Osservatore Romano” 10 (1983), s. 6-7, w tekście KPR z odnośnym numerem. 
dojrzewania i młodzieńczy charakteryzują się dążeniem do samodzielności i niezależności w dziedzinie wychowawczej, a dotąd wiodącą rolę w życiu dziecka spełniali rodzice. Młody członek zwraca uwagę na to, co wiąże się z jego osobistym wyborem. A wybiera według akceptowanych przez siebie wartości. W młodzieńczym wieku o słuszny wybór nie jest łatwo. Pojawiają się różne trudności, zwątpienia i załamania, i to głównie na płaszczyźnie religijnej, moralnej, środowiskowej (konflikty z rodziną - ucieczki z domu, kłopoty w szkole) i w nauce. W tej sytuacji młody człowiek zdany jest na walkę o ideały, wartości, które jak gdyby musi odzyskać na nowo. Właśnie ten Pan Jezus, z którym jako dziecko zżył się przy żłobeczku na Boże Narodzenie i przy grobie na Wielkanoc, teraz staje się Chrystusem zwątpienia, a może i przejściowego odrzucenia. Zresztą jest to Chrystus jego rodziców, dziadków, całej tradycji i kultury, w której wzrastał od dzieciństwa. Dopiero w momencie, gdy Chrystus-Bóg wchodzi na nowo w myśli, uczucia i dążenia dojrzewającego człowieka, gdy staje się kamieniem węgielnym tej budowy (por. Dz 3, 11), która jest krzepnąca osobowość ludzka, wtedy z psychologicznego punktu widzenia staje się moim Bogiem, przeze mnie wybranym. Gdyż jak to stwierdzono na płaszczyźnie nauki psychologii religii: „Bóg nie jest stworzony lecz wybierany"6.

Dwunastoletni Jezus w świątyni jerozolimskiej dokonuje wyboru w swej podmiotowości i bystrości umysłu: ,powinienem być w tym, co należy do mojego Ojca". Bóg Ojciec jest dla Syna - Jezusa z Nazaretu najważniejszy. Jest to szczególne zjednoczenie Syna z Ojcem, gdy jako dwunastoletni chłopiec deklaruje, że chce być w tym, co należy do jego Ojca.

Przyznać należy, że w naturalny sposób ważną rolę odegrali w owym doświadczeniu Boga Ojca przez Jezusa - Maryja i Józef. Zabrali Go przecież do świątyni. Nie pozostawili samemu sobie, lecz z bólem serca poszukiwali Go, aż do odnalezienia i spotkania. Czynili to ciągle razem. Przecież Józef mógłby powiedzieć do Maryi: «to twój Syn, poszukaj Go sama...» Józef tego nie powiedział, bo był „człowiekiem sprawiedliwym” (Mt 1, 19) i w sprawie Jezusa całkowicie zawierzył Bogu. Poszukując działali razem. Razem też Maryja z Józefem mówi o bólu z powodu zaginięcia Jezusa. Tak więc w trudnych chwilach poszukiwania i w radości odnalezienia budują wzajemnie autorytet rodzicielski. Jakże tego wzajemnego wspierania się rodzicielskiego autorytetu potrzebują dzisiaj wszystkie dzieci.

Dzieci zaś w okresie dorastania, patrząc na rodziców, którzy przeżywają wiarę na co dzień, wskazują kierunek drogi synom i córkom, dokonują wyboru na wzór Jezusa i naśladują Go. Nie odrzucają rodzinnego domu: ojca i matki, braci i sióstr, lecz przeciwnie, podobnie jak Jezus, który „,poszedł

${ }^{6}$ K. G. Jung, Psychologia a religia, Warszawa 1972, s. 175. 
z nimi, wrócił do Nazaretu i był im poddany" (Łk 2, 51), jako dorastające i dorosłe dzieci świadomie i odpowiedzialnie razem z rodzicami tworzą rodzinny dom.

Niezwykle ważnym świadectwem wiary rodziców wobec dzieci jest realizacja ich powołania miłości i życia, którą ukazują im w sakramencie małżeństwa, żyjąc miłością jedyną, wierną i wyłączną. Przez poddanie swojej płciowości błogosławieństwu Bożemu w płodności (por. Rdz 1, 28), osłaniają przed dziećmi tajemnicę ludzkiego zjednoczenia ze Stwórcą - w prokreacji. W pryzmacie miłości rodzicielskiej swoich rodziców dzieci poznają: że „kobieta staje wobec mężczyzny jako matka - podmiot nowego ludzkiego życia, które w niej się poczyna i rozwija, i z niej też rodzi się na świat. Poprzez to zaś odsłania się zarazem do końca tajemnica męskości mężczyzny: rodzicielskie, ojcowskie znaczenie jego ciała" ". Chrześcijańscy rodzice wskazują dzieciom na sens i znaczenie ludzkiego ciała, wraz z jego płciowością, przez które człowiek jest ściśle zjednoczony z Bogiem, uobecniając swoje istnienie wśród świata stworzeń. Dla swojego życia przemijającego, doczesnego, w Stwórcy odkrywają sens i wartość bytowania tu na ziemi i na wieczną przyszłość w zmartwychwstałym Chrystusie ${ }^{8}$.

Te aspekty życia rodzinnego uświęcił Pan Jezus, żyjąc w ludzkiej rodzinie Maryi i Józefa w Nazarecie, a poprzez Kanę Galilejską i naukę, którą głosił o małżeństwie i rodzinie, wnosi je w Duchu Świętym i w Kościele we współczesny świat.

\section{Parental Authority as Observed in the Holy Family of Nazareth and Nowadays} (Summary)

The Family of Nazareth was not formed according to natural law, yet according to the law revealed by God to Mary ( $\mathrm{Lu} 1: 26-38)$ and Joseph (Mt 1: 18-24).

Obeying the will of Heavenly Father, the spouses, Mary and Joseph, accepted the Son of God as a human being, since Jesus was brought up as the son of Joseph the Carpenter in the city of Nazareth.

Jesus was raised under the Law of Moses and Jewish tradition, which stressed respect for parental authority, especially that of a father.

7 Jan Paweł II, Mę̇̇czyznq i niewiasta stworzył ich, Watykan 1986, s. 70.

${ }^{8}$ Por. J. Śledzianowski, Wychowanie religijne a kultura życia rodzinnego, w: J. Śledzianowski (red.), Kultura pokoju w rodzinie i przez rodzinę, Kielce 2000, s. 114-122. 
The respect for parental authority of St Joseph as the legal father of Jesus (according to Jewish and Roman laws) is manifested through the words uttered by Mary to her 12 year-old son in the Jerusalem Temple: "Son, why hast thou thus dealt with us? Behold, thy father and I have sought thee sorrowing" (Lu 2: 49) - the King James's Bible.

Mutual respect between parents, the idea of sharing all the sorrows and joys, especially those connected with the upbringing of their children, is the very foundation of an appropriate development of a young generation. 